\title{
Characteristics of M30 Grade Concrete using Copper Slag as Partial Replacement for River Sand as Fine Aggregate
}

\author{
P. Sarath $^{1}$, B.Taruni ${ }^{2}$, G. Gowtham ${ }^{3} \&$ M. Bhargavi ${ }^{4}$ \\ ${ }^{1-4}$ Assistant Professor \\ Department of Civil Engineering, \\ Satya Institute of Technology and Management \\ Vizianagaram, Andhra Pradesh \\ India
}

\begin{abstract}
Concrete is the preferred construction material for a wide range of buildings, bridges and any other civil engineering structures. It is the second most widely consumed substance on earth after water. Aggregates are considered as one of the main constituents of concrete since they occupy 70-80\% of the volume of concrete. In many countries, there is a scarcity of natural aggregates. To reduce dependence on natural aggregates as the main source of aggregate in concrete, artificially manufactured aggregates generated from industrial wastes provide an alternative for the construction industry. Copper slag is one such industrial waste that can be implemented as an alternative for natural aggregate. Copper slag is an excellent by-product or waste material that retains its original properties. Due to its chemical composition which includes high iron, silica and aluminum oxide content, it can be used as a partial replacement for sand in concrete mixes. This paper emphasizes on COPPER SLAG CONCRETE which is a new evolution in the field of concrete design. Copper slag upon using as a partial replacement for river sand as fine aggregate can avoid the voids in the concrete and may increase the durability and strength of structure. In this study M30 grade concrete mixes of 30\%, 40\% and 50\% replacement of river sand with copper slag are tested for compressive, split tensile and flexural strengths for the ages of 1, 3, 7, 28, 56 and 91 days of curing.
\end{abstract}

Key Words: Copper slag, Copper slag concrete, Fine Aggregate, M30 Grade Concrete.

\section{INTRODUCTION}

Concrete is the man made material widely used for construction purposes. It is a popular building material in the world for past 170 years and more. The usual ingredients in concrete are cement, fine aggregate, coarse aggregate, and water. Although worldwide used concrete has disadvantages such as scarcity in availability of natural aggregates like river sand which is used as fine aggregate in concrete, consumption of aggregates in construction industry globally are still projected at an increase of more than 51 billion metric tons by 2021. Such large consumption of natural aggregates will cause destruction to the environment. To overcome this issue, industrial wastes should be used as an alternative to naturally available aggregates. The beneficial use of industrial by-products in concrete is well known for many years with regard to the use of materials such as coal ash, fly ash, pulverized fuel ash, bottom ash, blast furnace slag and silica fume as partial replacement for Portland cement or as fine aggregate.

Natural resources are depleting worldwide while at the same time the generated wastes from the industry are increasing substantially. The sustainable development for construction involves the use of non-conventional and innovative materials. This can be achieved by recycling of waste materials in order to compensate the lack of natural resources and to find alternative ways for conserving the environment.

\subsection{Copper Slag}

Copper slag is produced as a by-product of metallurgical operations in reverberator furnaces. For every ton of copper production, about 2.2 tons of copper slag is generated. Earlier copper slag was used as an abrasive material for removing rust and marine deposits from ships through sand blasting. After repetitive recycling and reuse, the copper slag lost its original abrasive property and with no good use thereafter, it was disposed in landfills. Industries found a novel way of encapsulating this waste into concrete, thereby not only removing the environmental concern but also finding a value-added and meaningful substitute for natural sand. 
Copper slag is totally inert material and its physical properties are similar to natural sand. Copper slag when grounded fine can be used as a replacement for sand in concrete which provides potential, environmental as well as economic benefits for all related industries. The major constituent of a smelting charge are sulphides and oxides of iron and copper. The charge also contains oxides such as $\mathrm{SiO} 2, \mathrm{Al} 2 \mathrm{O} 3, \mathrm{CaO}$ and $\mathrm{MgO}$ which are either present in original concentrate or added as flux. It is Iron, Copper, Sulphur, Oxygen and their oxides which largely control the chemistry and physical constitution of smelting system.

Copper slag concrete historically has been utilized in a variety of ways. Though most copper processing facilities currently recycle or dispose of their slag, there are numerous opportunities for utilization. The application that could potentially use the largest quantities of copper slag is using it as a highway construction aggregate. Copper slag has also been utilized for construction purposes in the past, but all facilities currently generating dispose of them.

\section{OBJECTIVE OF STUDY}

The objective of the present study is to determine and compare the properties of copper slag concrete with that of conventional concrete in terms of workability, compressive strength, split tensile strength and flexural strength.

\section{SCOPE OF STUDY}

The scope of the present investigation is to study and evaluate the effect of replacement of river sand with copper slag in concrete and to evaluate the strength characteristics of copper slag concrete in terms of compressive, split tensile and flexural strengths, a total of 4 mixes were cast with different proportions of copper slag as a replacement of fine aggregate $(0 \%, 30 \%, 40 \%$, $50 \%$ ) and optimum dosage is found out. Later for this optimum dosage, compressive strength, split tensile strength and flexural strength tests were carried out. In all mixes, the same type of aggregate i.e. crushed granite aggregate, river sand and the same proportion of fine aggregate to total aggregate are used. The relative proportions of cement, coarse aggregate, sand and water are obtained by IS - Code method. M30 grade of concrete is considered as a reference mix. Cubes of standard size $150 \mathrm{~mm}$ x $150 \mathrm{~mm}$ x $150 \mathrm{~mm}$ (length $\mathrm{x}$ breadth $\mathrm{x}$ height) were cast and tested for 1, 3, 7 and 28 days compressive strength. Standard cylinders of size $150 \mathrm{~mm} \times 300 \mathrm{~mm}$ (length $\mathrm{x}$ breadth) were cast and tested for1, 3, 7, 28, 56 and 91days split tensile strength. Standard beams of size $500 \mathrm{~mm} \times 100 \mathrm{~mm} \times 100 \mathrm{~mm}$ (length x breadth x height) were cast and were tested for 1, 3, 7, 28, 56 and 91 days flexural strength.

\section{EXPERIMENTAL DETAILS}

In the present investigation, the following materials were used

- $\quad$ Ordinary Portland Cement of 53 Grade cement conforming to IS: 169-1989.

- $\quad$ River sand of zone-II is used as fine aggregate conforming to IS: 2386-1963.

- Crushed granite material with $60 \%$ passing $20 \mathrm{~mm}$ and retained on $10 \mathrm{~mm}$ sieve, $40 \%$ passing $10 \mathrm{~mm}$ and retained on $4.75 \mathrm{~mm}$ sieve is used as coarse aggregate.

- Copper slag.

- Potable fresh water free from concentration of acid or organic substances was used for mixing the concrete.

\subsection{Cement}

Ordinary Portland cement (OPC) is the commonly used cement in general uses throughout the world as a prime ingredient of concrete, mortar. Ordinary Portland Cement of 53 Grade of brand name Ultratech, available in the local market was used for the investigation. The physical properties of the cement are listed in Table 1

Table.1 Physical properties of cement

\begin{tabular}{|c|c|c|}
\hline S.no. & Property & Value \\
\hline 1. & Specific Gravity & 3.01 \\
\hline 2. & Fineness of cement (By sieving) & $2.75 \%$ \\
\hline 3. & Standard Consistency & $31 \%$ \\
\hline 4. & Setting Time & 115 minutes \\
\cline { 2 - 3 } & i) Initial setting time & 253 minutes \\
\hline
\end{tabular}




\subsection{Fine Aggregate}

Natural River sand is used as fine aggregate. The physical properties of sand are listed in Table 2.

Table 2. Physical properties of sand

\begin{tabular}{|c|c|c|}
\hline S.no. & Property & Value \\
\hline 1. & Grading of Sand & Zone II as per IS 383 \\
\hline 2. & Specific Gravity & 2.61 \\
\hline 3. & Fineness Modulus & 2.66 \\
\hline
\end{tabular}

\subsection{Coarse Aggregate}

Aggregates typically make up about 60 to $80 \%$ of the volume of concrete mixture. The aggregates of size $10 \mathrm{~mm}$ and $20 \mathrm{~mm}$ of following physical properties are used in present investigation.

Table 3. Physical properties of coarse aggregates

\begin{tabular}{|c|c|c|}
\hline S.no. & Property & Value \\
\hline 1. & Specific Gravity & 2.74 \\
\hline 2. & Fineness Modulus & 6.76 \\
\hline 3. & Water Absorption & $1 \%$ \\
\hline
\end{tabular}

\subsection{Copper slag}

Copper slag is a by-product obtained during the matte smelting and refining of copper. Copper slag is also called as Ferro sand. Copper slag is a black glassy and granular in nature and has similar particle size range like sand. It is also found that the copper slag has less moisture content so it has less heat of hydration. The glass content of slag is suitable for blending with Portland cement typically varies between $90-100 \%$ and depends on the cooling method and the temperature at which cooling is initiated. The glass structure of the quenched glass largely depends on the proportions of network-forming elements such as $\mathrm{Si}$ and $\mathrm{Al}$ over network-modifiers such as $\mathrm{Ca}, \mathrm{Mg}$ and to a lesser extent $\mathrm{Al}$. The physical and chemical properties of copper slag are listed in Table 4 and Table 5 respectively.

Table 4. Physical properties of copper slag

\begin{tabular}{|l|c|c|}
\hline S.no. & Physical properties & Suggested values by supplier \\
\hline 1. & Colour & Black \\
\hline 2. & Specific Gravity & 3.77 \\
\hline 3. & Fineness & $3.44 \%$ \\
\hline
\end{tabular}

Table 5. Chemical properties of copper slag

\begin{tabular}{|c|c|c|}
\hline S.no. & Chemical component & \% of chemical component \\
\hline 1 & $\mathrm{SiO}_{2}$ & 25.42 \\
\hline 2 & $\mathrm{Fe}_{2}$ & 68.79 \\
\hline 3 & $\mathrm{Al}_{2} \mathrm{O}_{3}$ & 0.21 \\
\hline 4 & $\mathrm{CaO}$ & 0.14 \\
\hline 5 & $\mathrm{Na}_{2} \mathrm{O}$ & 0.55 \\
\hline 6 & $\mathrm{~K}_{2} \mathrm{O}$ & 0.22 \\
\hline 7 & $\mathrm{MnO}_{3}$ & 0.24 \\
\hline 8 & $\mathrm{TiO}_{2}$ & 0.39 \\
\hline 9 & $\mathrm{SO}_{3}$ & 14.38 \\
\hline 10 & $\mathrm{CuO}$ & 6.53 \\
\hline
\end{tabular}




\subsection{Water}

The water used for mixing and curing should be clean and free from hazardous impurities such as alkalis, acids, oils, salt, sugar, organic materials, vegetable growth and other substances that may be deleterious to bricks, stone, concrete or steel. Potable water is generally considered satisfactory for mixing. The $\mathbf{p H}$ value of water should not be less than 6 .

\subsection{Mix Proportions}

In this study, mix design is carried out according to IS $10262: 2009$. M30 grade of concrete was designed. The control mix (Mix 0) has proportion (by weight) of 1(cement): 1.82(fine aggregate): 3.18(coarse aggregate) and water to cement ratio(w/c) is 0.45 . In mixes Mix-1, Mix-2 and Mix-3, river sand(fine aggregate) is partially replaced with $30 \%, 40 \%$ and $50 \%$ copper slag respectively.

Table 6. Mix proportions of M30 concrete

\begin{tabular}{|c|l|l|l|l|l|}
\hline $\begin{array}{c}\text { Mix } \\
\text { designation }\end{array}$ & $\begin{array}{c}\text { Water } \\
\left(\mathbf{l t} / \mathbf{m}^{\mathbf{3}}\right)\end{array}$ & $\begin{array}{c}\text { Cement } \\
\left(\mathbf{k g} / \mathbf{m}^{\mathbf{3}}\right)\end{array}$ & $\begin{array}{c}\text { Fine } \\
\mathbf{a g g r e g a t e} \\
\mathbf{( k g / \mathbf { m } ^ { 3 } )}\end{array}$ & $\begin{array}{c}\text { Coarse } \\
\mathbf{a g g r e g a t e} \\
\left(\mathbf{k g} / \mathbf{m}^{\mathbf{3}}\right)\end{array}$ & $\begin{array}{c}\text { Copper } \\
\mathbf{s l a g} \\
\left(\mathbf{k g} / \mathbf{m}^{\mathbf{3}}\right)\end{array}$ \\
\hline Mix-0 & 171 & 380 & 694.95 & 1209.79 & 0 \\
\hline Mix-1 & 171 & 380 & 486.47 & 1209.79 & 208.49 \\
\hline Mix-2 & 171 & 380 & 416.97 & 1209.79 & 277.9 \\
\hline Mix-3 & 171 & 380 & 347.46 & 1209.79 & 347.46 \\
\hline
\end{tabular}

\subsection{Preliminary Investigations}

In the preliminary investigation, so as to obtain the optimum percentage replacement of fine aggregate with copper slag, tests like workability and compressive strength were conducted on 30\%, $40 \%$ and $50 \%$ replacement of fine aggregate with copper slag. Workability is conducted in terms of compacting factor test. The variation of compaction factor and compressive strength for respective percentages of fine aggregate replacement with copper slag are tabulated below

Table 7. Variation of compaction factor

\begin{tabular}{|c|c|c|c|c|}
\hline Grade of Concrete & \multicolumn{3}{|c|}{ M30 } \\
\hline $\begin{array}{c}\text { Percentage } \\
\begin{array}{c}\text { Replacement of } \\
\text { Copper slag concrete }\end{array}\end{array}$ & $\begin{array}{c}\text { Mix }-\mathbf{0} \\
(\mathbf{0 \%} \mathbf{C S})\end{array}$ & $\begin{array}{c}\text { Mix }-\mathbf{1} \\
(\mathbf{3 0 \%} \mathbf{C S})\end{array}$ & $\begin{array}{c}\text { Mix }-\mathbf{2} \\
\mathbf{( 4 0 \%} \mathbf{C S})\end{array}$ & $\begin{array}{c}\text { Mix }-\mathbf{3} \\
(\mathbf{5 0 \%} \mathbf{C S})\end{array}$ \\
\hline Compaction Factor & 0.89 & 0.88 & 0.87 & 0.85 \\
\hline
\end{tabular}


International Journal of Engineering Research And Advanced Technology, Vol.7 (5), May -2021

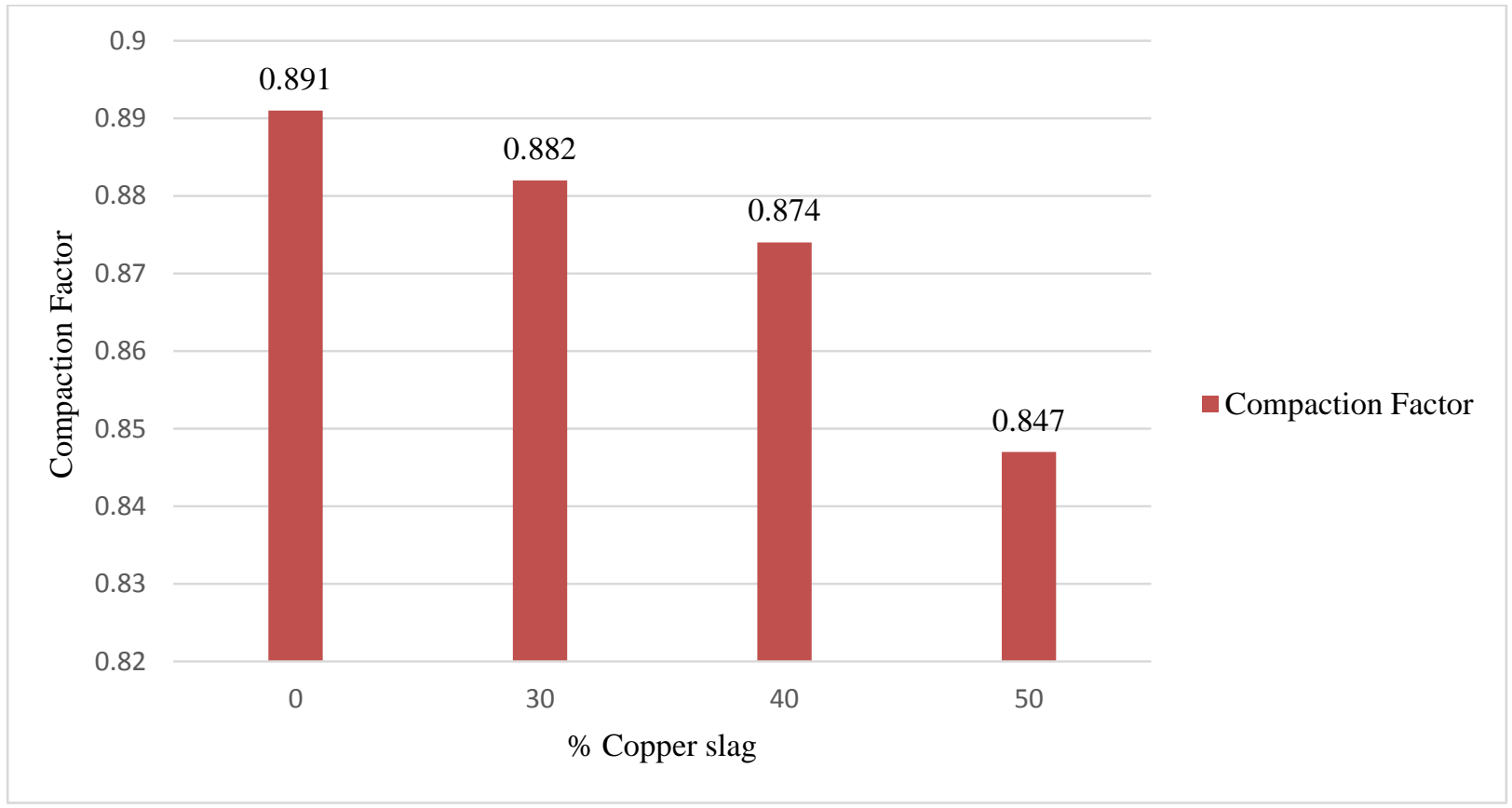

Figure1. Variation of workability (compaction factor)

Table 8. Variation of compressive strength for 7 and 28 days curing

\begin{tabular}{|c|c|c|c|c|}
\hline \multirow{2}{*}{ Age(days) } & \multicolumn{4}{|c|}{ Compressive strength(MPa) } \\
\cline { 2 - 5 } & $\begin{array}{c}\text { Mix }-\mathbf{0} \\
(\mathbf{0 \%} \mathbf{C S})\end{array}$ & $\begin{array}{c}\text { Mix }-\mathbf{1} \\
\mathbf{( 3 0 \%} \mathbf{C S})\end{array}$ & $\begin{array}{c}\text { Mix }-\mathbf{2} \\
\mathbf{( 4 0 \%} \mathbf{C S})\end{array}$ & $\begin{array}{c}\text { Mix }-\mathbf{3} \\
(\mathbf{5 0 \%} \mathbf{C S})\end{array}$ \\
\hline $\mathbf{7}$ & 28.29 & 27.81 & 42.51 & 24.88 \\
\hline $\mathbf{2 8}$ & 42.03 & 30.57 & 53.48 & 32.79 \\
\hline
\end{tabular}

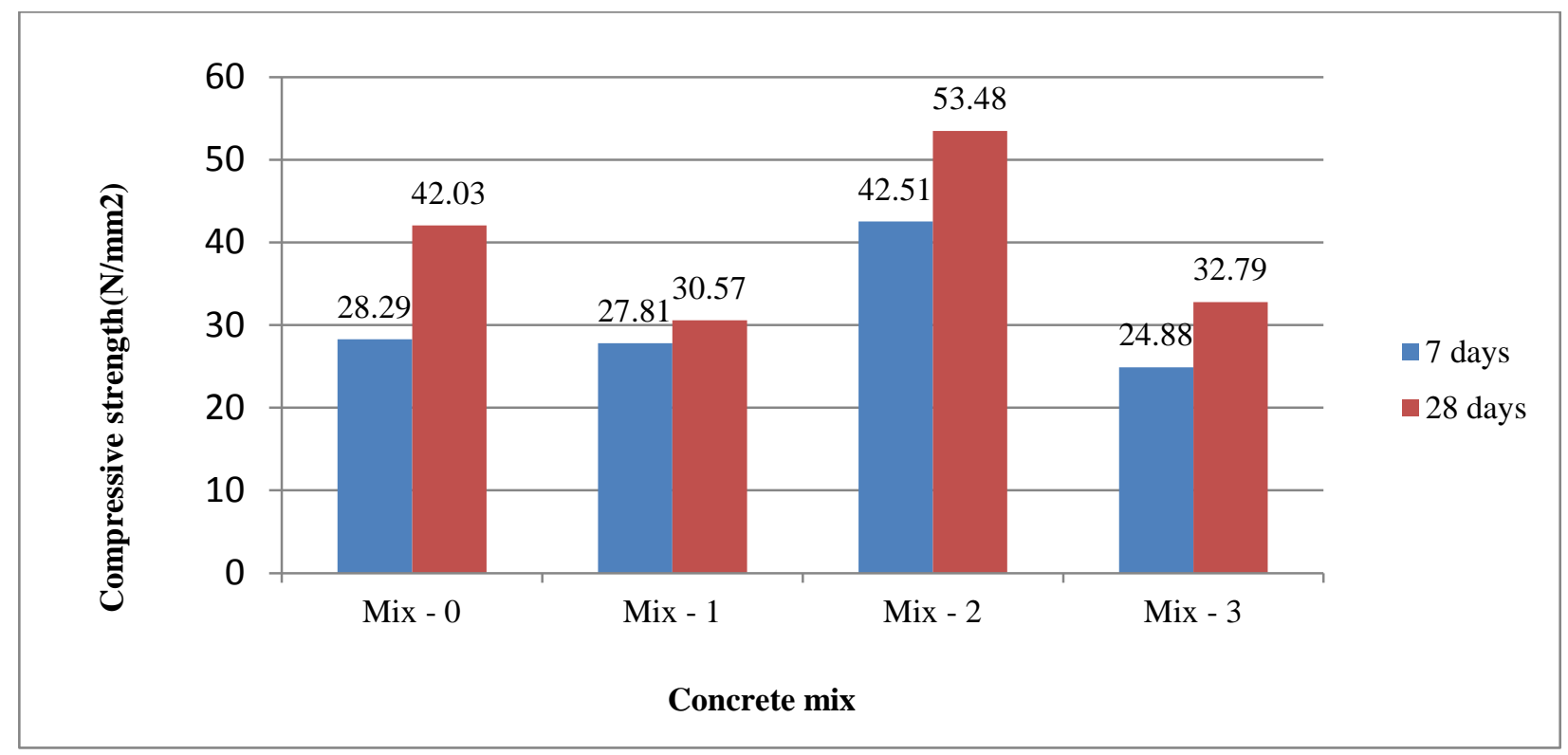

Figure 2. Variation of compressive strength for 7 and 28 days curing 
It has been observed that $40 \%$ replacement of fine aggregate with copper slag (Mix-2) is giving better results when compared with other replacements. Hence, we can conclude $40 \%$ replacement of fine aggregate with copper slag as the optimum dosage.

\section{RESULTS AND DISCUSSION}

\subsection{Workability in terms of Compaction Factor}

The values of compaction factor obtained in the present investigation for various percentages of replacement of fine aggregate with Copper slag are shown in Table 7. It can be observed that as the percentage of the replacement of fine aggregate with Copper slag increases the compaction factor decreases. Hence it can be concluded that as the percentage of Copper slag increases the workability decreases.

\subsection{Compressive strength of M30 grade Concrete}

Compressive strength test has been conducted on cubes of standard size $150 \mathrm{~mm}$ x $150 \mathrm{~mm}$ x $150 \mathrm{~mm}$ for all mixes and resulting compressive strength obtained at the age of 1, 3, 7, 28, 56 and 91 days for M30 grade concrete were tabulated in the table 8, 9and fig 3. It can be seen that the compressive strength of concrete with fine aggregate replaced by Copper slag is more than the conventional concrete mix at all ages.

Table.9 Compressive strength of M30 grade concrete with $40 \%$ replacement of fine aggregate by copper slag

\begin{tabular}{|c|c|c|}
\hline \multirow{2}{*}{ Age (days) } & \multicolumn{2}{|c|}{$\begin{array}{c}\text { Compressive strength } \\
\text { (MPa) }\end{array}$} \\
\cline { 2 - 3 } & $\mathbf{0 \%}$ CS & $\mathbf{4 0 \%}$ CS \\
\hline $\mathbf{1}$ & 19.91 & 27.84 \\
\hline $\mathbf{3}$ & 26 & 35.7 \\
\hline $\mathbf{7}$ & 28.29 & 42.51 \\
\hline $\mathbf{2 8}$ & 42.03 & 53.48 \\
\hline $\mathbf{5 6}$ & 45.7 & 53.72 \\
\hline $\mathbf{9 1}$ & 46.6 & 53.86 \\
\hline
\end{tabular}

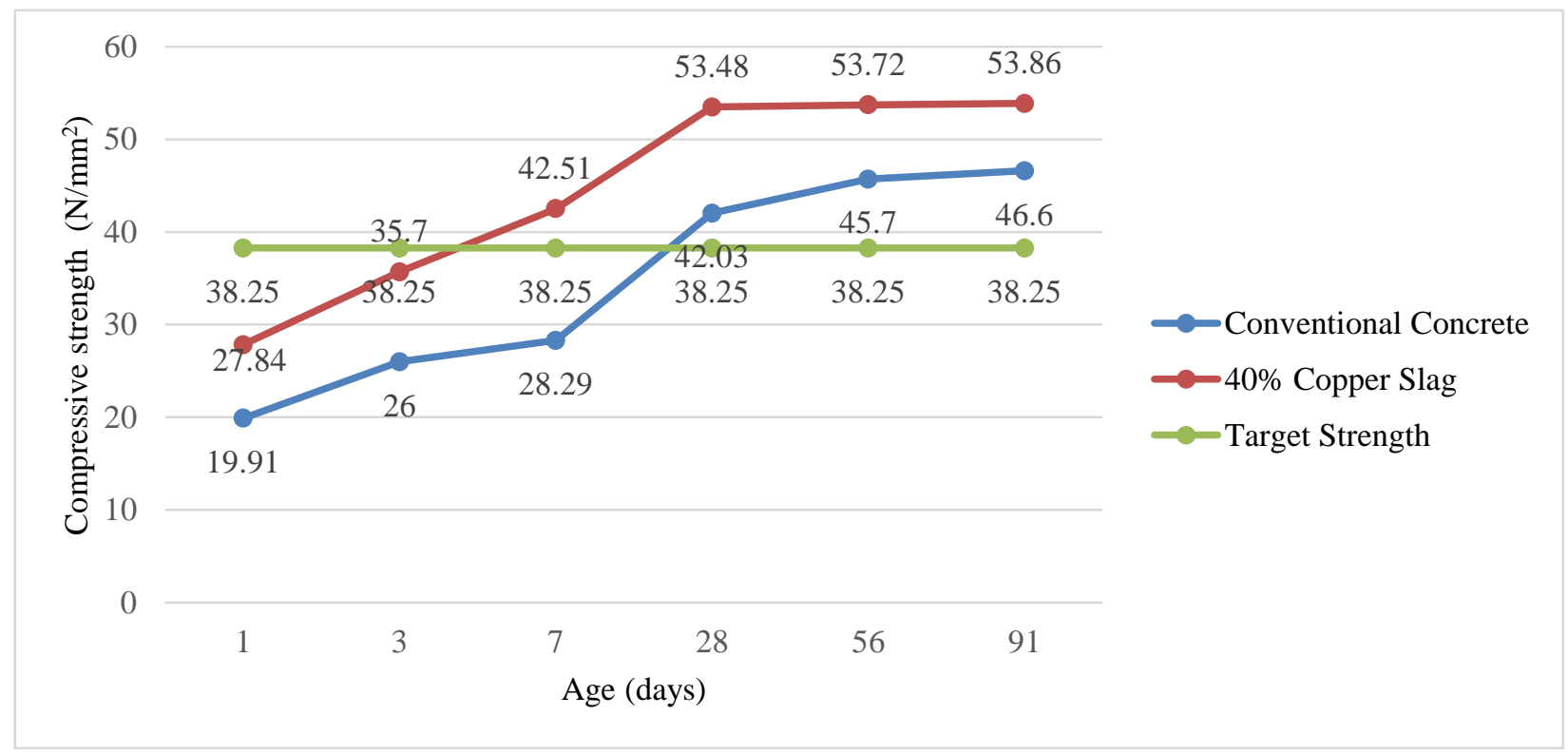

Figure 3. Variation of compressive strength with age for conventional concrete and $40 \%$ copper slag concrete

Observation: It is observed that $40 \%$ replacement of natural sand by Copper slag is giving better compressive strength for M30 grade concrete compared to other proportions of mixes for all ages. 


\subsection{Split Tensile strength test}

Split tensile strength test has been conducted on cylinders of size $150 \mathrm{~mm}$ x $300 \mathrm{~mm}$ for all mixes and resulting split tensile strength obtained at the age of 1, 3, 7, 28, 56 and 91 days for M30 grade concrete were tabulated in the table 10 and fig.4. It can be seen that the split tensile strength of concrete with fine aggregate replaced by Copper slag is more than the conventional concrete mix at later ages.

Table: 10. Split tensile strength of M30 grade concrete with $40 \%$ replacement of fine aggregate by copper slag

\begin{tabular}{|c|c|c|}
\hline \multirow{2}{*}{ Age (days) } & \multicolumn{2}{|c|}{$\begin{array}{c}\text { Split Tensile strength } \\
\text { (MPa) }\end{array}$} \\
\cline { 2 - 3 } & $\mathbf{0 \% C S}$ & $\mathbf{4 0 \%}$ CS \\
\hline $\mathbf{1}$ & 1.59 & 1.93 \\
\hline $\mathbf{3}$ & 1.88 & 2.19 \\
\hline $\mathbf{7}$ & 2.49 & 2.68 \\
\hline $\mathbf{2 8}$ & 2.87 & 2.89 \\
\hline $\mathbf{5 6}$ & 3.25 & 3.49 \\
\hline $\mathbf{9 1}$ & 3.34 & 3.72 \\
\hline
\end{tabular}

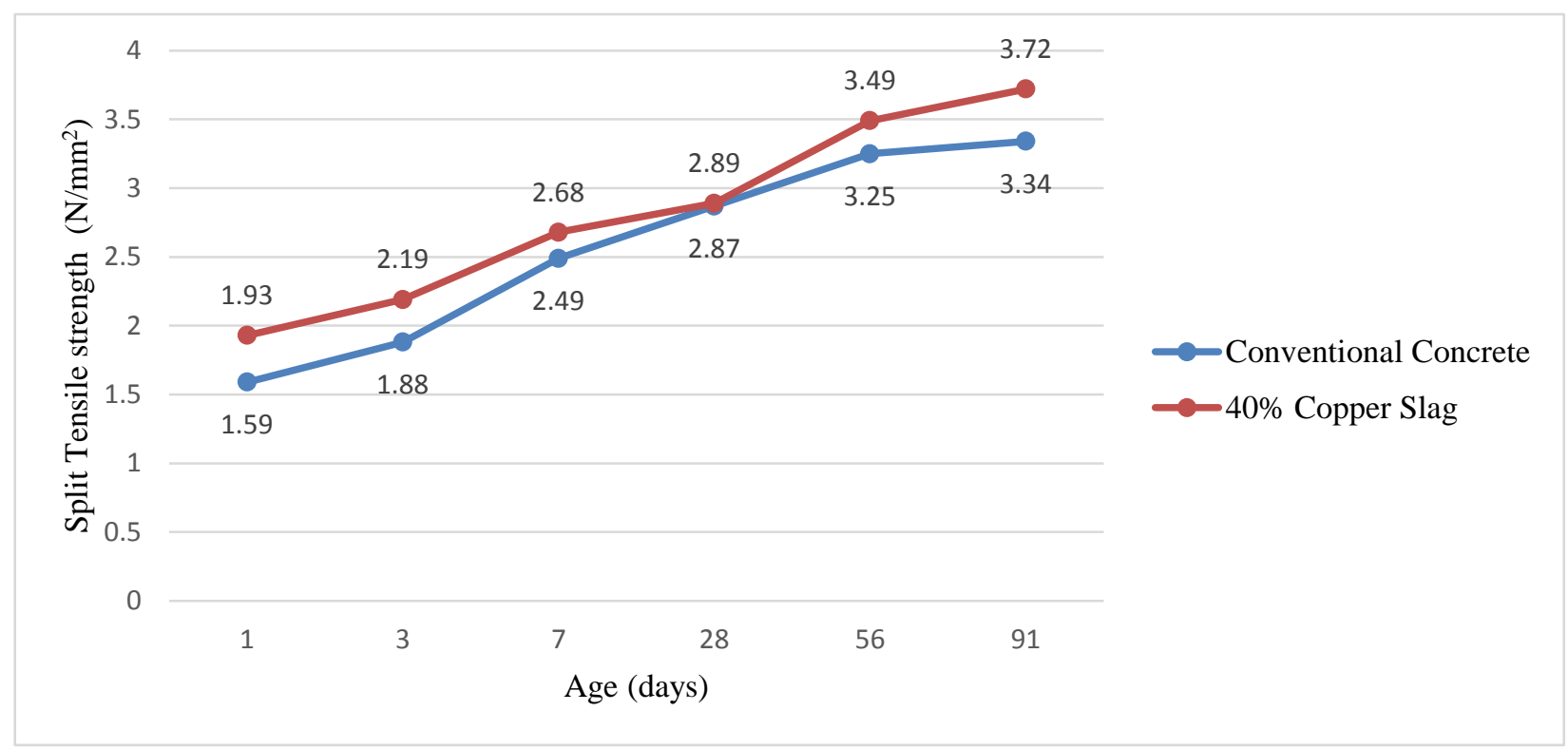

Figure 4. Variation of split tensile strength with age for conventional concrete and copper slag concrete

Observation: It is observed that $40 \%$ replacement of natural sand by Copper slag is giving better split tensile strength for M30 grade concrete compared to other proportions of mixes for later ages (28,56 and 91 days).

\subsection{Flexural Strength test}

Flexural strength test has been conducted on beams of size $500 \mathrm{~mm} \times 100 \mathrm{~mm} \times 100 \mathrm{~mm}$ for all mixes and resulting flexural strength obtained at the age of 1, 3, 7, 28, 56 and 91 days for M30 grade of concrete were tabulated in the Table 11 and Fig.5. It can be seen that the flexural strength of concrete with fine aggregate replaced by Copper slag is more than the conventional concrete mix at later ages.

Table: 11. Flexural strength of M30 grade concrete with 40\% replacement of fine aggregate by copper slag

\begin{tabular}{|c|c|c|}
\hline \multirow[t]{2}{*}{ Age (days) } & \multicolumn{2}{|c|}{$\begin{array}{c}\text { Flexural strength } \\
\text { (MPa) }\end{array}$} \\
\hline & $0 \% \mathrm{CS}$ & $40 \% \mathrm{CS}$ \\
\hline 1 & 3.71 & 3.21 \\
\hline 3 & 4.57 & 4.49 \\
\hline 7 & 5.69 & 4.86 \\
\hline 28 & 5.85 & 5.96 \\
\hline 56 & 6.19 & 6.32 \\
\hline 91 & 6.28 & 7.34 \\
\hline
\end{tabular}


International Journal of Engineering Research And Advanced Technology, Vol.7 (5), May -2021

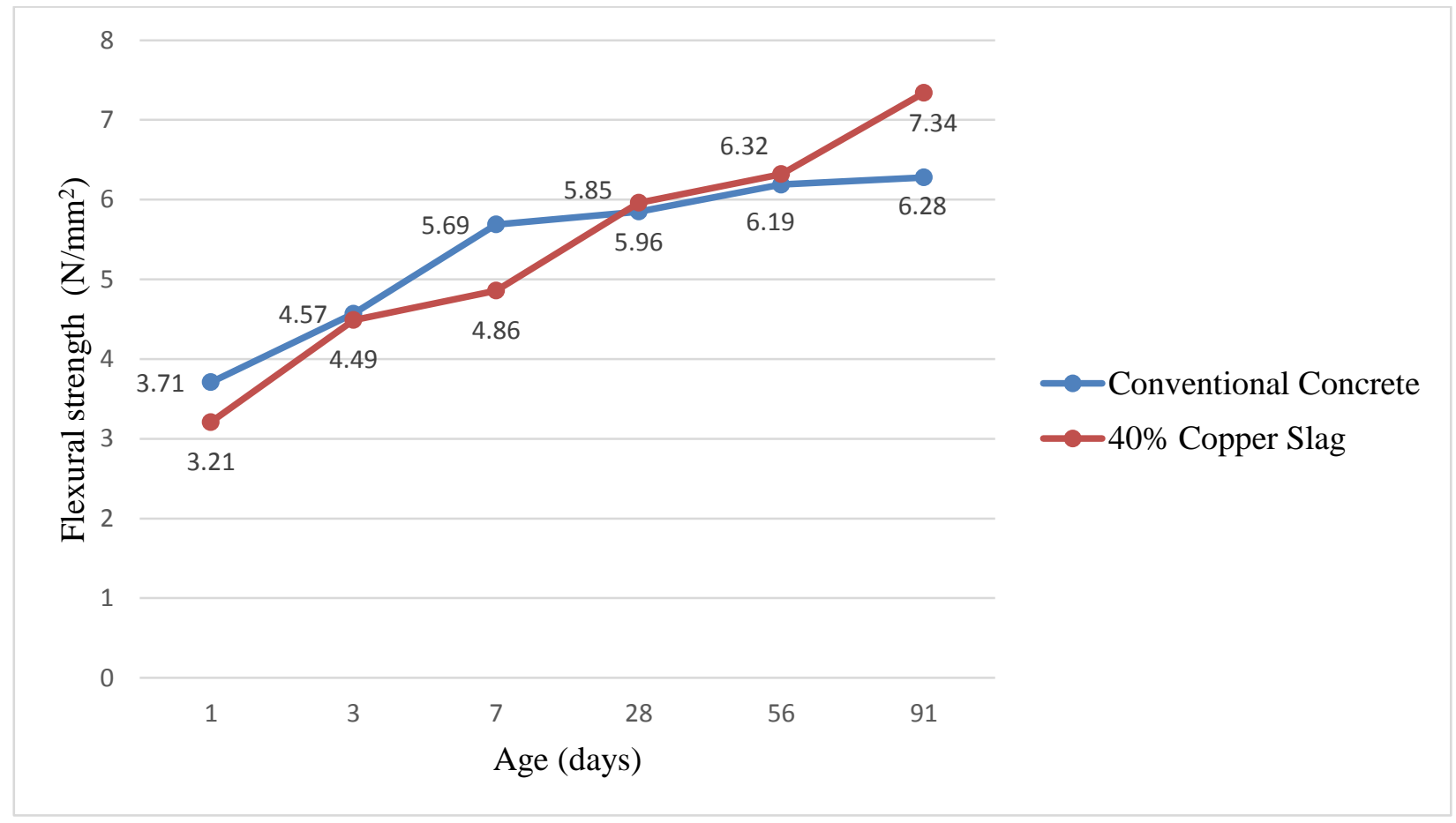

Figure 5. Variation of flexural strength with age for conventional concrete and copper slag concrete

Observation: It is observed that $40 \%$ replacement of natural sand by Copper slag is giving better flexural strength for M30 grade concrete compared to other proportions of mixes for later ages $(28,56,91$ days $)$

\section{CONCLUSIONS}

1. The compaction factor values of concrete with Copper slag are observed to be relatively less when compared to conventional concrete, as Copper slag has more water absorption capacity compared to the river sand. Therefore, workability of concrete decreases significantly with the increase of Copper slag percentage in concrete.

2. The Copper slag can be used as a best alternative material for partial replacement of natural sand and gives more compressive strength in order of $15 \%$ to $50 \%$ for M30 grade concrete than conventional concrete.

3. It is observed that $40 \%$ replacement of natural sand by Copper slag is giving better compressive strength when compared to other proportions $(0 \%, 30 \%$ and $50 \%)$ of mixes for 7 and 28 days.

4. It is observed that $40 \%$ replacement of natural sand by Copper slag is giving better split tensile strength when compared to other proportions of mixes for later ages (28,56,91 days).

5. It is observed that $40 \%$ replacement of natural sand by Copper slag is giving better flexural strength, when compared to other proportions of mixes for later ages (28,56,91 days).

6. The compressive strength of copper slag concrete is of order $39.83 \%, 37.30 \%, 50.26 \%, 27.24 \%, 17.5 \%, 15.5 \%$ more for $1,3,7,28,56$ and 91 days respectively, when compared with conventional concrete.

7. The split tensile strength of copper slag concrete is of order $21.38 \%, 16.48 \%, 7.6 \%, 0.69 \%, 7.38 \%, 11.37 \%$ more for $1,3,7$, 28,56 and 91days respectively, when compared with conventional concrete.

8. The flexural strength is of copper slag concrete is of order $13.4 \%, 1.75 \%, 14.58 \%, 1.88 \%, 2.10 \%, 16.87 \%$ more for 1,3 , 7, 28, 56, 91 days respectively, when compared with conventional concrete.

\section{REFERENCES}

[1] Alnuaimi AS, (2012), “Effects of Copper slag concrete as a Replacement for Fine Aggregate in the behavior and ultimate strength of reinforced concrete slender columns”, ITJER, Vol. 9, No.2, pp 90-102

[2] Antonio M. Arino and BarzinMobasher, "Effect of ground copper slag concrete on strength and toughness of cementitious mixes", ACI material Journal, Vol.96, No.1, pp 68-74 
[3] Binod Kumar, (2012), "Properties of pavement quality concrete and dry lean concrete with copper slag concrete as fine aggregate" International Journal of Pavement Engineering, vol. 1, pp1-6.

[4] Brindha.D and Nagan.S, "Durability studies on copper slag concrete admixed concrete", Asian journal of civil engineering (Building and Housing) Vol. 12, NO. S pages 563-578(2011)

[5] Chavan R and Kulkarni D B international "Performance of copper slag concrete on strength properties as partial replacement of fine aggregate in concrete Mix Design", Journal of Civil and Structural Engineering Volume 1 No.4 (2011)

[6] LavanyaCet al "Review On Utilization of Copper slag concrete in geo-technical Applications", PaperNo.H-212(2011).

[7] Meenakshi, et al "Performance of Copper slag concrete and ferrous slag as partial replacement of sand in concrete", International Journal of Advanced Engineering Research and Studies.(2013)

[8] Nagan.S, et al“Assessment of Corrosion and Durability Characteristics of Copper slag concrete Admixed Concrete", International Journal of civil and structural engineering volume no. 2

[9] Pundhir NKS et al. "Use of copper slag concrete as construction material in bituminous pavements", Journal of Scientific \&industrial research vol 64 (2005) 